\title{
AMS RADIOCARBON DATING OF ICE: VALIDITY OF THE TECHNIQUE AND THE PROBLEM OF COSMOGENIC IN-SITU PRODUCTION IN POLAR ICE CORES
}

A. T. WILSON

Department of Geosciences, The University of Arizona, Tucson, Arizona 85721 USA

and

\section{J. DONAHUE}

NSF-Arizona Accelerator Facility for Radioisotope Analysis, The University of Arizona, Tucson Arizona 85721 USA

ABSTRACT. In the "sublimation technique," carbon dioxide entrapped in ice is recovered by sublimation, converted to graphite and ratio of ${ }^{14} \mathrm{C} /{ }^{13} \mathrm{C}$ in the $\mathrm{CO}_{2}$ determined by AMS measurements. We describe here several experiments performed to check the validity of such measurements and to study the effect of cosmogenically produced in-situ ${ }^{14} \mathrm{C}$ on the measurements.

\section{INTRODUCTION}

Polar ice sheets have become an important source of paleoenvironmental information. Ice cores taken from polar ice sheets provide an excellent opportunity for studying the Earth's atmosphere at times in the past. The most reliable dating of ice cores older than the limit of annual isotopic stratigraphy (9-12 ka BP) may be through ${ }^{14} \mathrm{C}$ measurements on the $\mathrm{CO}_{2}$ contained in the ice. We have developed a "sublimation" technique for recovering small amounts of $\mathrm{CO}_{2}$ in atmospheric air entrapped in polar ice cores. The basic technique was reported at the 13th International Radiocarbon Conference (Wilson \& Donahue 1989). We discuss here two important questions concerning the ${ }^{14} \mathrm{C}$ dating of the $\mathrm{CO}_{2}$ entrapped in ice. We study the reliability of the method by determining the ${ }^{14} \mathrm{C}$ ages of known-age samples dated by other methods, and we investigate the effect of in-situ, cosmogenically produced ${ }^{14} \mathrm{C}$ that may be present in ice cores.

\section{THE SUBLIMATION TECHNIQUE FOR THE ${ }^{14} \mathrm{C}$ DATING OF ICE CORES}

Two serious problems must be overcome to measure successfully the ${ }^{14} \mathrm{C}$ content of $\mathrm{CO}_{2}$ trapped in polar ice:

1. The core contains extremely small amounts of carbon. A kilogram of ice from a polar ice sheet contains, depending on the surface altitude of the ice sheet, about 15 to $20 \mu \mathrm{g}$ of carbon as $\mathrm{CO}_{2}$. Most ice cores are only about $10 \mathrm{~cm}$ in diameter, which makes it difficult to obtain very large samples of ice for dating. In addition to making detection of ${ }^{14} \mathrm{C}$ difficult, the small quantities of carbon exacerbate the problem of correcting for background (chemical blank) carbon accumulated during sample processing and target preparation.

2. The polar ice cores may contain a considerable amount of carbon as solid carbonate particles - wind blown loess. It is important to prevent the exchange of $\mathrm{CO}_{2}$ carbon with carbonate carbon.

Our technique, described in detail in Wilson and Donahue $(1989,1990)$ enables us to carbon date the atmospheric gases trapped in as little as $0.5-3 \mathrm{~kg}$ of ice, depending on its $\mathrm{CO}_{2}$ content. The technique involves placing the ice sample in a carefully degassed glass vacuum system, "cleaning" the ice by removing the outer few millimeters by sublimation, then subliming the ice completely, 
using infrared lamps as an energy source. The water vapor pressure is monitored to ensure that the surface of the ice is always below $-10^{\circ} \mathrm{C}$. It is important to keep the temperature of the ice well below $0^{\circ} \mathrm{C}$ to prevent any exchange of sample $\mathrm{CO}_{2}$ with carbonate loess that might be present in the ice sample. The gases evolved from the subliming ice first pass through a trap at $-80^{\circ} \mathrm{C}$ to remove water. The remaining gases pass through a trap immersed in liquid nitrogen where the $\mathrm{CO}_{2}$ is recovered. The gases that pass the liquid nitrogen trap are trapped on a molecular sieve held at liquid nitrogen temperatures.

In our apparatus, we can sublime a $3-\mathrm{kg}$ sample of ice core in $18 \mathrm{~h}$. We measure the quantity of water sublimed, the amount of air and $\mathrm{CO}_{2}$ recovered and the ${ }^{14} \mathrm{C}$ content of the $\mathrm{CO}_{2}$. From these data, we can calculate the $\mathrm{CO}_{2}$ concentration of the atmosphere at the time given by our ${ }^{14} \mathrm{C}$ date. So far, we have processed various kinds of natural ice ranging in difficulty from ice from ice caves to ice cores from polar ice sheets.

Ice-cave ice is essentially frozen groundwater that had been in contact with the soil atmosphere and contains $>1000 \mu \mathrm{g}$ of $\mathrm{CO}_{2}$ carbon $\mathrm{kg}^{-1}$ ice. We need only $100 \mathrm{~g}$ samples to date this type of ice. At the other end of the scale of difficulty is ice from high-altitude, high-latitude ice sheets. This ice has never been liquid water, and we recover the $\mathrm{CO}_{2}$ from air trapped in bubbles when the snow was compressed into ice at the firn/ice transition. Since these samples usually come from high altitudes, the air pressure can be significantly lower than that at sea level. These samples contain about $15 \mu \mathrm{g}$ of $\mathrm{CO}_{2}$ carbon $\mathrm{kg}^{-1}$ ice. Besides the problem of recovery, they present a problem of measuring ${ }^{14} \mathrm{C}$ in samples of very small size.

Intermediate between these two extremes is temperate alpine glacier ice. The surface snow that ultimately forms these glaciers has usually undergone some melting and refreezing, which leads to the incorporation of atmospheric $\mathrm{CO}_{2}$ into the ice crystals. With polar ice-core samples, we normally use $2-3 \mathrm{~kg}$ samples, and we can now routinely run $60-\mu \mathrm{g}$ graphite samples in our AMS facility. Smaller samples are precisely diluted with ${ }^{14} \mathrm{C}$-free $\mathrm{CO}_{2}$, to bring the AMS target size to about $60-100 \mu \mathrm{g}$. We have run polar ice samples as small as $1 \mathrm{~kg}$ in the "bomb pulse" zone where the activity is high and the spatial resolution in the ice core is of concern. This work was undertaken to determine the "offset" between the age of the air and the age of the ice that entraps it. In polar-ice cores, the age of the ice that is entrapping the air may have fallen as snow hundreds (in the case of Greenland ice cores) to many thousands of years ago (in the case of ice cores from the central part of the Antarctic Ice sheet).

\section{VALIDITY OF THE ${ }^{14}$ C DATING OF ICE}

\section{Ice-Cave Ice}

Caves containing bodies of ice occur in many parts of the world. Little is known about the mechanics of the ice bodies in these caves, and many questions remain unanswered. How long has ice been in these caves? Did the ice survive the Medieval Warm period? What is the distribution of the age within the ice body? Does the ice contain any paleoclimatic information? ${ }^{14} \mathrm{C}$ dating of the ice may provide a way of obtaining the answers to some of these questions. The ice is very easy to date, as it contains, by polar ice core standards, very large quantities of $\mathrm{CO}_{2}$. Thus, samples of only $100 \mathrm{~g}$ are required. Presumably, the ice is frozen groundwater that has been in contact with the soil atmosphere, which is high in $\mathrm{CO}_{2}$ due to the respiration of plant roots. The question is, if we recover $\mathrm{CO}_{2}$ from this "cave ice" and determine its ${ }^{14} \mathrm{C} /{ }^{13} \mathrm{C}$ ratio, do we calculate a valid date for the ice? We have dated many samples from the ice caves in New Mexico, and, in the course of this work, were able to obtain dates for both a normal sample (bird feather, twig) and the ice that entrapped it. The data are given in Table 1 . One can see that the ${ }^{14} \mathrm{C}$ dates of the conventional 
materials are the same as the $\mathrm{CO}_{2}$ entrapped in the ice that encloses them. This gives us confidence that the dates we are obtaining from the ice samples not associated with organic remains are also valid.

TABLE 1. Radiocarbon Dating Carbon Dioxide of Ice from the Candelaria Ice Cave, New Mexico

\begin{tabular}{llr}
\hline Sample no. & \multicolumn{1}{c}{ Source of $\mathrm{CO}_{2}$} & ${ }^{14} \mathrm{C}$ date $(\mathrm{yr} \mathrm{BP})$ \\
\hline AA-6022 & Ice & $55 \pm 60$ \\
AA-6023D2 & Bird feather in ice sample AA-6022 & $25 \pm 70$ \\
AA-4915 & Ice from base of deposit & $1780 \pm 60$ \\
AA-6021 & Ice from base of deposit & $1860 \pm 60$ \\
GX-15919 & Twig embedded in ice sample AA-6021 & $1810 \pm 100$ \\
\hline
\end{tabular}

\section{RADIOCARBON DATING OF POLAR ICE CORES}

An excellent source of known-age air entrapped in polar ice is air that is just older than atmospheric weapons tests. Wilson and Donahue (1990) determined the depth in the GISP-2 core at which bomb-produced ${ }^{14} \mathrm{C}$ is present. By choosing samples from depths just below this level, we are assured that they contain air that was in the atmosphere between AD 1900 and 1940. The ${ }^{14} \mathrm{C}$ content of this air is precisely known from tree-ring studies. One would expect that measurements on samples from this depth would provide a sensitive check of the validity of our technique.

However, the fact that polar ice can contain some cosmic-ray-produced, in-situ ${ }^{14} \mathrm{C}$ complicates these considerations. Lal et al. (1990) reported the observation of cosmogenic in-situ ${ }^{14} \mathrm{C}$ in ablating ice from the Allen Hills area of Antarctica. In addition, Lal and Jull (1990) calculated that a considerable amount of in-situ ${ }^{14} \mathrm{C}$ could be formed on the surface of an accumulating ice sheet. Their calculations show, for example, that if all in-situ ${ }^{14} \mathrm{C}$ produced in the surface snow at the GISP-2 site were retained during the firnification process to be entrapped in the ice below the firn/ice transition, a correction of $1.6 \mathrm{ka}$ would have to be made to our results. If even a small fraction of in-situ ${ }^{14} \mathrm{C}$ were to be retained through the firnification process, important corrections would have to be made to determine ice-core ages from measurements on sublimed $\mathrm{CO}_{2}$. To study the effects of this in-situ ${ }^{14} \mathrm{C}$, we used samples of the GISP-2 ice core from depths just below the region containing the nuclear weapons pulse, the region just below $90 \mathrm{~m}$ (Wilson \& Donahue 1990). Results of measurements on $\mathrm{CO}_{2}$ extracted from two samples at this depth are shown in Table 2.

TABLE 2. Samples from the GISP-2 Ice Core

\begin{tabular}{lcccc}
\hline Sample No. & Depth $(\mathrm{m})$ & $\mathrm{F}^{*}{ }_{\text {measured }}$ & $\mathrm{F}_{\text {tre-ring }}$ & $\begin{array}{l}\text { Ratio } \\
\text { ice/tree }\end{array}$ \\
\hline AA-5293D4 & 90.6 & $0.98 \pm 0.03$ & $0.978 \pm 0.005$ & $1.002 \pm 0.03$ \\
AA-6323 & 91.4 & $0.992 \pm 0.008$ & $0.978 \pm 0.005$ & $1.014 \pm 0.009$ \\
& & & Weighted average & $1.013 \pm 0.009$ \\
\hline
\end{tabular}

${ }^{*} \mathrm{~F}=\frac{\left({ }^{14} \mathrm{C} /{ }^{13} \mathrm{C}\right)_{\text {sample }} ; \delta=-25 \% 0}{\left({ }^{14} \mathrm{C} /{ }^{13} \mathrm{C}\right)_{1950} ; \delta=-25 \% 0}$ 
From the results presented in this table, two observations can be made. By the time the snow at the surface of Summit (GISP-2 ice core) has moved down to the firn/ice boundary, essentially all of the cosmic-ray-produced in-situ ${ }^{14} \mathrm{C}$ in $\mathrm{CO}_{2}$ has escaped to the atmosphere. Our results indicate that less than $3 \%$ of the ${ }^{14} \mathrm{C}$ in the $\mathrm{CO}_{2}$ recovered with our system could be from cosmogenic in-situ ${ }^{14} \mathrm{C}$. Presumably, the in-situ ${ }^{14} \mathrm{C}$ escapes to the atmosphere during the recrystallization involved in the firnification process.

Perhaps the most important result of this work was that it provided an important check on our technique for the ${ }^{14} \mathrm{C}$ dating of polar ice cores. For an ice sample with a precisely known date, our results agree within our experimental errors, which in the best case, are less than $1 \%$, with results obtained from tree-ring measurements. This provides evidence that, at least in the Holocene portion of the GISP-2 core, we have not overlooked some important phenomenon. This also gives us some confidence that our procedure for ${ }^{14} \mathrm{C}$ dating the air trapped in polar ice cores does enable us to produce correct dates for the Holocene portion of the GISP-2 core. It is interesting to note that our dating of the undiluted $\mathrm{CO}_{2}$ from the $5-\mathrm{kg}$ ice sample used in this work provided results of comparable accuracy to routine AMS ${ }^{14} \mathrm{C}$ dating of more conventional materials.

The production and retention of cosmogenic in-situ ${ }^{14} \mathrm{C}$ in ice cores can depend sensitively on the geographical location at which those cores were drilled. For example, Lal and Jull (1990) calculate that, because of the low accumulation rate in the Antarctic, cosmogenic in-situ ${ }^{14} \mathrm{C}$ at the site of the Vostok core should be approximately ten times that at Summit in Greenland (GISP-2). We have recently performed an experiment similar to the one described above for a sample from a depth of $112 \mathrm{~m}$ at Vostok. This depth should correspond to an air age of about $600 \mathrm{yr}$. One would expect the specific activity of the carbon in the $\mathrm{CO}_{2}$ in the air extracted from this ice core sample to be about $93 \%$ of "modern" (1950). We found it to be $2.344 \pm 0.013$ times "modern." Our measured result is

$$
\mathrm{F}_{\text {measured }}=2.344 \pm 0.013 \text {, }
$$

so that the ratio

$$
\frac{\mathrm{F}_{\text {ice-measured }}}{\mathrm{F}_{\text {air-expected }}}=2.344 / 0.93=2.52
$$

It is clear that a great deal of cosmic-ray-produced in-situ ${ }^{14} \mathrm{C}$ is retained in the Vostok core, and any ${ }^{14} \mathrm{C}$ dating of this core will have to correct for this phenomenon. However, a correction can be made, so that accurate dates can be obtained, at least for the Holocene. Our Vostok sample was stored in a trench at Vostok for about one year. Depending on the degree of shielding it experienced, a fraction between 0 and $1 / 3$ of the cosmogenic ${ }^{14} \mathrm{C}$ that we observed could be from "post-coring" cosmic-ray-induced reactions.

A comparison of experimental and calculated results (Lal \& Jull 1990) for the Vostok core indicates that as much as $25 \%$ of the in-situ ${ }^{14} \mathrm{C}$ cosmogenically produced in the surface snow at Vostok is retained through the firnification process, and is present in ice below the firn/ice transition. This result was obtained using the fact that ice contains about $15 \mu \mathrm{g}$ of carbon trapped as $\mathrm{CO}_{2} \mathrm{~kg}^{-1}$ of ice, and assuming that in-situ-produced ${ }^{14} \mathrm{C}$ is $50 \%$ in $\mathrm{CO}$ and $50 \%$ in $\mathrm{CO}_{2}(\mathrm{Lal}$ et al. 1990). Whereas almost none of the original ice matrix at Summit is retained, the situation is very different at Vostok, possibly due to the fact that the firn at Vostok is $25^{\circ} \mathrm{C}$ colder than at Summit (GISP-2). 
The above measurements at $112 \mathrm{~m}$ in the Vostok core provide in-situ ${ }^{14} \mathrm{C}$ corrections, which must be applied to any ${ }^{14} \mathrm{C}$ dating of the Vostok core in Holocene times. It is likely that the correction will be different during glacial times, when conditions were colder and accumulation rate was less. It is also possible that some cosmogenic in-situ ${ }^{14} \mathrm{C}$ was retained in GISP-2 ice during glacial times, when the temperature and accumulation rate were lower than they are now. The possible presence of cosmogenically produced in-situ ${ }^{14} \mathrm{C}$ must be carefully considered when interpreting ${ }^{14} \mathrm{C}$ age measurements of polar ice.

\section{ACKNOWLEDGMENT}

This work was supported in part by NSF Grant DPP-8821916. This is contribution No. 91-11 from the Greenland Ice Sheet Program Two (GISP-2).

\section{REFERENCES}

Lal, D. and Jull, A. J. T. 1990 On determining ice accumulation rates in the past 40,000 years using in-situ cosmogenic ${ }^{14} \mathrm{C}$. Geophysical Research Letters 17: 1303-1306.

Lal, D., Jull, A. J. T., Donahue, D. J., Burtner, D. and Nishiizumi, K. 1990 Polar ice ablation rates based on in-situ cosmogenic ${ }^{14} \mathrm{C}$. Nature 346: 350-352.

Wilson, A. T. and Donahue, D. J. 1989 The recovery

and dating of $\mathrm{CO}_{2}$ in polar ice cores. In Long, A. and $\mathrm{Kra}, \mathrm{R}$. S., eds., Proceedings of the 13th International ${ }^{14} \mathrm{C}$ Conference. Radiocarbon 31(3): 579-584.

1990 AMS carbon-14 dating of ice: Progress and future prospects. In Yiou, F. and Raisbeck, G. M., eds., Proceedings of the 5th International Conference on Accelerator Mass Spectrometry. Nuclear Instruments and Methods B52: 473-476. 